Jurnal Kesehatan

Volume 11, Nomor 1, Tahun 2020

ISSN 2086-7751 (Print), ISSN 2548-5695 (Online)

http://ejurnal.poltekkes-tjk.ac.id/index.php/JK

\title{
Sanitasi Pemukiman pada Masyarakat dengan Riwayat Penyakit Berbasis
} Lingkungan

\section{Sanitation of Community Settlements with a History of Environmental- Based Diseases}

Mei Ahyanti

Jurusan Kesehatan Lingkungan, Politeknik Kesehatan Tanjung Karang, Indonesia

\section{ARTICLE INFO}

\section{Article history:}

Received date

24 Jan 2020

Revised date

29 Jan 2020

02 Mar 2020

Accepted date

26 Apr 2020

\section{Keywords:}

Sanitation;

Settlement;

PBL.

\section{Kata kunci:}

Sanitasi;

Pemukiman;

PBL.

\author{
ABSTRACT/ ABSTRAK
}

\begin{abstract}
Environmental-based diseases (PBL) are a health problem and occur in almost all geographical regions in the world. Every year, environment-based diseases are always found and reported to spread evenly at every Puskesmas in Bandar Lampung City. Settlement sanitation is an important aspect directly related to health and society. "Waterborne Disease" disease is still high, proving that there are still sanitation problems in settlements. The study aims to determine the relationship of settlement sanitation with environmental-based diseases in the city of Bandar Lampung. The study used a cross-sectional design, the population is all households in Bandar Lampung City. The sample was 384 respondents, taken randomly using multistage sampling. The results found $14,3 \%$ of respondents had a physical component of an unhealthy house, $45,3 \%$ of respondents had an unhealthy sanitation facility, $40,1 \%$ of the occupants of the house behaved in an unhealthy manner. The test results statistically concluded that there was a significant relationship between settlement sanitation and the incidence of environmental-based diseases.
\end{abstract}

Penyakit berbasis lingkungan (PBL) merupakan masalah kesehatan dan terjadi hampir di seluruh daerah geografis di dunia. Setiap tahun penyakit berbasis lingkungan selalu ditemukan dan dilaporkan menyebar merata pada setiap Puskesmas di Kota Bandar Lampung.Sanitasi pemukiman merupakan aspek penting terkait langsung dengan kesehatan dan masyarakat. Penyakit "Waterborne Desease" masih tinggi, membuktikan bahwa masih terdapat masalah sanitasi di pemukiman. Penelitian bertujuan untuk mengetahui hubungan sanitasi pemukiman dengan penyakit berbasis lingkungan di Kota Bandar Lampung. Penelitianmenggunakan rancangan crossectional, populasi adalah seluruh rumah tangga yang ada di Kota Bandarlampung. Sampel berjumlah 384 responden, diambil secara random menggunakan multistage sampling. Hasil penelitian mendapatkan $14,3 \%$ responden memiliki komponen fisik rumah tidak sehat, 45,3\% responden memiliki sarana sanitasi yang tidak sehat, 40,1\% penghuni rumah berperilaku tidak sehat. Hasil uji secara statistik menyimpulkan ada hubungan yang bermakna antara sanitasi pemukiman dengan kejadian penyakit berbasis lingkungan.

Corresponding Author:

Mei Ahyanti

Jurusan Kesehatan Lingkungan, Politeknik Kesehatan Tanjung Karang, Indonesia

Email: mei.ahyanti@gmail.com

\section{PENDAHULUAN}

Penyakit berbasis lingkungan merupakan masalah kesehatan dan terjadi hampir di seluruh daerah geografis di dunia, termasuk Indonesia (Darnas \& Yolanda, 2019). Penyakit berbasis lingkungan dapat terjadi karena adanya hubungan interaktif antara manusia, perilaku serta komponen lingkungan yang memiliki potensi penyakit (Achmadi, 2008). Salah satu tantangan yang paling utama bagi negara-negara berkembang adalah sanitasi. Penyakit infeksi 
yang diakibatkan oleh faktor lingkungan dan selalu masuk dalam 10 besar penyakit hampir di seluruh puskesmas di Indonesia adalah Infeksi saluran pernafasan akut (ISPA) dan diare. Selain itu malaria, demam berdarah dengue (DBD), cacingan, filaria, TB paru, penyakit kulit dan keracunan.

Angka kesakitan (Insidens Rate) diare untuk semua kelompok umur di Provinsi Lampung dari tahun 2005-2014 cenderung meningkat, yaitu dari 9,8 per 1000 penduduk menjadi 21,4 per 1000 penduduk tahun 2013. Angka kesakitan DBD di Provinsi Lampung tahun 2015 sebesar 36,91 per 100.000 penduduk (dibawah IR Nasional yaitu 51 per 100.000 penduduk) dengan Angka Bebas Jentik (ABJ) kurang dari 95\% (Dinas Kesehatan Provinsi Lampung, 2016).

Setiap tahun di Kota Bandar Lampung selalu ditemukan dan dilaporkan menyebar merata di setiap Puskesmas. Tren diare semua umur tahun 2014-2016 cenderung meningkat. Insiden diare tahun 2014 sebanyak 17,60 per 1000 penduduk, tahun 201518,23 per 1000 penduduk dan tahun 201621,69 per 1000 penduduk.

ISPA juga merupakan penyakit yang selalu masuk dalam 10 besar penyakit yang ada di Kota Bandar Lampung (Dinas Kesehatan Kota Bandar Lampung, 2017). Peta pola difusi kasus DBD dilihat dari faktor kepadatan penduduk tahun 2016, persebaran wilayah dengan pola persebaran paling besar di area Rajabasa, Tanjung Senang Way Halim, Tanjung Karang Pusat dengan jumlah kasus 97-117, dan daerah Kemiling, Langkapura, Tanjungkarang Barat, Teluk Betung Utara, Teluk Betung Selatan, Bumi Waras, Teluk Betung Timur dengan jumlah Kasus 70-93 (Qamila\& Krama, 2018).

Sanitasi pemukiman merupakan aspek penting yang terkait langsung dengan kesehatan dan masyarakat. Masih tingginya angka kesakitan khususnya penyakit "Waterborne disease" membuktikan bahwa masih terdapat masalah sanitasi pemukiman.

\section{METODE}

Penelitian jenis deskriptif analistik ini menggunakan rancangan cross-sectional. Penelitian dilaksanakan di Bandar Lampung pada Bulan Agustus hingga Desember 2018. Populasi adalah seluruh rumah tangga yang ada di Kota Bandar Lampung. Sampel berjumlah 384 rumah diperoleh melalui perhitungan menggunakan rumus estimasi proporsi dengan presisi mutlak (Ariawan, 1998). Proses pengambilan sampel secara bertingkat (Multi Stage Sampling). Penelitian diarahkan untuk menganalisis kondisi sanitasi pemukiman masyarakat dengan riwayat penyakit berbasis lingkungan di Kota Bandar Lampung menggunakan uji Chi Square.

Penelitian ini telah mendapatkan Keterangan Kelaikan Etik (Ethical Clearance) dengan Nomor 247/EC/KEP-TJK/IX/2018 oleh Komisi Etik Penelitian Kesehatan Kementerian Kesehatan Tanjung Karang.

\section{HASIL}

Tabel 1. Distribusi Responden berdasarkan Komponen Sanitasi Pemukiman

\begin{tabular}{lrr}
\hline Komponen Sanitasi Pemukiman & Jumlah & \% \\
\hline Komponen Fisik Rumah & & \\
\hline Komponen fisik rumah tidak sehat & 55 & 14,3 \\
Komponen fisik rumah sehat & 329 & 85,7 \\
\hline Komponen Sarana Sanitasi & & \\
\hline Sarana Sanitasi tidak sehat & 174 & 45,3 \\
$\quad$ Sarana sanitasi sehat & 210 & 54,7 \\
\hline Komponen Perilaku Penghuni & & \\
\hline Perilaku tidak sehat & 154 & 40,1 \\
$\quad$ Perilaku sehat & 230 & 59,9 \\
\hline Sanitasi Pemukiman & & \\
\hline Pemukiman tidak sehat & 181 & 47,1 \\
$\quad$ Pemukiman sehat & 203 & 52,9 \\
\hline
\end{tabular}

Tabel 1 Menggambarkan hasil penilaian terhadap sanitasi pemukiman yang meliputi komponen fisik rumah, komponen sarana sanitasi, komponen perilaku penghuni. Selanjutnya dari ketiga komponen digabungkan menjadi satu penilaian sanitasi pemukiman. Terdapat $14,3 \%$ rumah yang memiliki komponen fisik rumah tidak sehat. 45,3\% rumah dengan kategori sarana sanitasi yang tidak sehat dan 40,1\% rumah dengan penghuni yang berperilaku tidak sehat. Dari Hasil penilaian secara keseluruhan dapat dinyatakan bahwa $47,1 \%$ rumah masuk dalam kategori pemukiman tidak sehat. 
Tabel 2. Distribusi Responden berdasarkan Komponen Sanitasi Pemukiman dengan Penyakit Berbasis Lingkungan

\begin{tabular}{|c|c|c|c|c|c|c|c|c|}
\hline \multirow{3}{*}{ Variabel } & \multicolumn{4}{|c|}{ Penyakit Berbasis Lingkungan } & \multirow{2}{*}{\multicolumn{2}{|c|}{ Total }} & \multirow{3}{*}{$p$-value } & \multirow{3}{*}{$\begin{array}{c}\text { OR } \\
\text { CI } 95 \%\end{array}$} \\
\hline & \multicolumn{2}{|c|}{ PBL } & \multicolumn{2}{|c|}{ Tidak PBL } & & & & \\
\hline & $\sum$ & $\%$ & $\sum$ & $\%$ & $\sum$ & $\%$ & & \\
\hline \multicolumn{9}{|c|}{ Komponen Fisik Rumah } \\
\hline Tidak Sehat & 29 & 52,7 & 26 & 47,3 & 55 & 100 & \multirow{2}{*}{0,045} & 1,868 \\
\hline Sehat & 123 & 37,4 & 206 & 62,6 & 329 & 100 & & $1,052-3,318$ \\
\hline \multicolumn{9}{|c|}{ Komponen Sarana Sanitasi } \\
\hline Tidak Sehat & 90 & 51,7 & 84 & 48,3 & 174 & 100 & \multirow{2}{*}{0,000} & 2,558 \\
\hline Sehat & 62 & 29,5 & 148 & 70,5 & 210 & 100 & & $1,681-3,892$ \\
\hline \multicolumn{9}{|c|}{ Komponen Perilaku Penghuni } \\
\hline Tidak Sehat & 73 & 47,4 & 81 & 52,6 & 154 & 100 & \multirow{2}{*}{0,014} & 1,723 \\
\hline Sehat & 79 & 34,3 & 151 & 65,7 & 230 & 100 & & $1,135-2,615$ \\
\hline \multicolumn{9}{|c|}{ Sanitasi Pemukiman } \\
\hline $\begin{array}{l}\text { Pemukiman } \\
\text { Tidak Sehat }\end{array}$ & 94 & 51,9 & 87 & 48,1 & 181 & 100 & \multirow{2}{*}{0,000} & \multirow{2}{*}{$\begin{array}{r}2,701 \\
1,772-4,118\end{array}$} \\
\hline $\begin{array}{l}\text { Pemukiman } \\
\text { Sehat }\end{array}$ & 58 & 28,6 & 145 & 71,4 & 203 & 100 & & \\
\hline
\end{tabular}

Dari tabel 2 dapat dijelaskan pada kelompok responden dengan sanitasi pemukiman tidak sehat terdapat $51,9 \%$ menderita penyakit berbasis lingkungan. Sedangkan pada kelompok responden dengan sanitasi pemukiman sehat terdapat $28,6 \%$ menderita penyakit berbasis lingkungan. Diperoleh $p$-value $=0,000 \mathrm{OR}=2,701$, CI 95\% 1,772-4,118. Dari hasil tersebut dapat disimpulkanterdapat hubungan yang bermakna antara sanitasi pemukiman dengan kejadian penyakit berbasis lingkungan di Kota Bandar Lampung.

\section{PEMBAHASAN}

Rumah adalah lambang status sosial (Mukono, 2006). Rumah juga lambang kesehatan penghuninya. Rumah memiliki tiga aspek yang perlu diperhatikan dalam mencapai sanitasi pemukiman dan merupakan hal pokok yang harus dipenuhi untuk menciptakan suasana sehat bagi penghuninya. Sanitasi pemukiman dilihat dari kelengkapan dan penggunaan komponen fisik rumah, sarana sanitasi yang tersedia dan penggunaannya serta perilaku dari penghuni rumah tersebut. Kriteria ini disusun berdasarkan pedoman Direktorat Jenderal Pengendalian Penyakit dan Penyehatan Lingkungan Departemen Kesehatan Republik Indonesia tahun 2007 tentang pedoman teknis penilaian rumah sehat.

\section{Penyakit Berbasis Lingkungan}

Penyakit berbasis lingkungan adalah problem masyarakat serius yang bahkan akibat yang ditimbulkannya adalah kematian. Terdapat
$39,6 \%$ responden dengan penyakit penyakit berbasis lingkungan yaitu ISPA, diare dan DBD. Penyakit-penyakit tersebut adalah penyakit yang hingga kini selalu menduduki peringkat dalam 10 besar penyakit yang dilaporkan oleh puskesmas. Penyakit berbasis lingkungan memiliki hubungan yang erat dengan kondisi lingkungan sekitar.

\section{Hubungan Komponen Fisik Rumah dengan Penyakit Berbasis Lingkungan}

Hasil penelitian pada tabel 1 mendapatkan responden yang memiliki komponen fisik rumah tidak sehat sebesar $14,3 \%$, sedangkan komponen fisik rumah sehat $85,7 \%$. Kondisi yang tersebut menunjukkan bahwa masyarakat sudah memiliki kesadaran dan kemampuan dalammembangun rumah yang memenuhi syarat kesehatan, namun masih ada rumah-rumah yang belum memenuhi syarat kesehatan.

Dari tabel 2 terlihat pada kelompok responden dengan komponen fisik rumah tidak sehat, ada $52,7 \%$ menderita penyakit berbasis lingkungan. Pada kelompok responden yang memiliki komponen fisik rumah sehat terdapat $37,4 \%$ menderita penyakit berbasis lingkungan. Hasil analisa secara statistik mendapatkan hubungan yang bermakna antara komponen fisik rumahdengan kejadian penyakit berbasis lingkungan, dimana nilai signifikansi sebesar $0,045 \quad(\mathrm{OR}=1,868 \quad \mathrm{CI}=1,052-3,318)$. Hasil tersebut menunjukkan bahwa kelompok responden dengan komponen fisik rumah yang tidak sehat berisiko 1,868 kali menderita penyakit berbasis lingkungan dibanding dengan kelompok responden dengan komponen fisik rumah yang sehat. 
Beberapa indikator yang digunakan dalam penilaian komponen fisik rumah adalah langitlangit, dinding rumah, lantai, jendela kamar tidur, jendela ruang keluarga, ventilasi, lubang asap dapur dan pencahayaan. Terdapat $14,3 \%$ yang tidak memiliki komponen fisik rumah yang memenuhi syarat. Komponen fisik rumah memiliki korelasi dengan kejadian penyakit infeksi pernafasan yaitu TB (Ambarwati, 2019). Paparan terhadap bahaya lingkungan berpengaruh terhadap penyakit infeksi seperti penyakit pernafasan (Boyd \& Genuis, 2008; Samani, Karimi, \& Alesheikh, 2020).

Komponen fisik langit-langit yang bersih dapat menghindarkan penghuninya dari paparan debu. Langit-langit dirancang sehingga memiliki fungsi untuk menutup seluruh konstruksi atap dan kuda-kuda penyangga, sehingga tidak rawan kecelakaan. Kecelakaan dapat diakibatkan karena jatuhnya kayu yang sudah rapuh. Langit-langit ini juga berfungsi sebagai penyekat yang dapat menyerap panas sehingga tidak mudah menjalar kedalam ruangan dibawahnya.

Dinding berfungsi sebagai pelindung rumah. Dinding permanen akan memberikan suasana kering dan kedap air. dinding memberikan kontribusi terhadap kelembaban sehingga menjadi tempat yang baik bagi perkembangbiakan mikroorganisme penular penyakit. Kenyataan yang ada, masih terdapat rumah dengan dinding semi permanen, rumah dengan pasangan bata namun tidak diplester serta dari papan yang tidak kedap air.

Masih terdapat rumah responden dengan lantai berbahan papan atau anyaman bambu dan rumah yang lantainya belum diplester dengan kondisi berdebu. Kondisi ini dapat menyebabkan terjadinya penyakit saluran pernafasan. Lantai yang baik harus terbuat dari bahan yang cukup kuat untuk menahan beban diatasnya sehingga tidak muda rusak, tidak licin, stabil, permukaan rata dan mudah dibersihkan.

Jendela dan ventilasi merupakan komponen fisik yang wajib ada dalam rumah. Keberadaan keduanya menciptakan suasana segar didalam ruangan, karena udara kotor dalam ruangan akan bertukar dengan udara segar dari luar melalui jendela dan ventilasi. Penelitian (Santoro, Rambi, \& Katiandagho, 2015) menyebutkan ventilasi rumah sebagai Faktor Risiko Terhadap Kejadian Penyakit ISPA. Hasil analisis menunjukkan bahwa ventilasi rumah yang tidak memenuhi syarat berisiko 4 kali lebih besar menyebabkan ISPA bagi penghuninya dibandingkan ventilasi rumah yang memenuhi syarat, nilai $p$-value $<\alpha 0,05$.
Jika tidak memungkinkan adanya jendela dan ventilasi yang dibuat di dinding rumah, dapat dibuat dengan menyediakan sedikit rongga di bagian atap rumah. Namun di Kota Bandar Lampung, karena terbatasnya lahan untuk tempat tinggal, masyarakat tinggal di perumahan dimana perumahan tersebut dibangun saling berdempetan satu dengan lainnya. Rumah diperluas dengan pembangunan gedung bertingkat sehingga tidak memungkinkan untuk dibuat ventilasi dibagian atap bagi bangunan yang dibawah. Kondisi seperti ini dapat di siasati dengan pemasangan ventilasi buatan/ air conditioner.

Komponen selanjutnya lubang asap dapur. Lubang asap dapur harus ada untuk penyaluran asap pada saat memasak. Asap yang terperangkap dan dihisap oleh penghuni rumah menyebabkan gangguan pernafasan. Masih terdapat responden yang tidak memiliki lubang asap dapur, dan ada responden yang telah memiliki lubang asap dapur namunjarang dibersihkan sehingga kotor. Bagi rumah yang tidak memungkinkan untuk dibuat lubang asap dapur, dapat memanfaatkan pintu atau jendela di dapur. Pintu dan jendela tersebut dibuka saat memasak, untuk menghindari terperangkapnya asap dapur. Keberadaan jendela dan ventilasi mendukung penyediaan pencahayaan dalam ruangan. Cahaya dalam ruangan dapat berasal dari cahaya alami yang masuk melalui jendela dan pintu yaitu sinar matahari. Ruangan yang tidak mendapatkan sinar matahari dapat dipasang lampu agar tidak gelap.

\section{Hubungan Sarana Sanitasi dengan Penyakit Berbasis Lingkungan}

Aspek kedua dalam penilaian sanitasi pemukiman adalah sarana sanitasi. Tabel 1 menggambarkan responden memiliki sarana sanitasi yang tidak sehat sebesar $45,3 \%$, dan $54,7 \%$ memiliki sarana sanitasi yang sehat.Beberapa indikator yang digunakan dalam penilaian sarana sanitasi adalah sarana air bersih, sarana pembuangan kotoran manusia, sarana pembuangan air limbah (SPAL), sarana pembuangan sampah, binatang penular penyakit, pekarangan dan kandang hewan.

Hasil analisa secara statistik pada tabel 2 menyimpulkan ada hubungan yang bermakna antara sarana sanitasi dengan kejadian penyakit berbasis lingkungan, dimana nilai signifikansi sebesar $\quad 0,000 \quad(\mathrm{OR}=2,558, \quad \mathrm{CI}=1,681-3,892)$. Artinya responden dengan sarana sanitasi tidak sehat berisiko 2,558 kali untuk menderita penyakit berbasis lingkungan dibandingkan dengan responden dengan sarana sanitasi sehat. 
Sarana air bersih yang tersedia akan memberikan kontribusi terhadap kualitas air bersih. Kualitas air bersih sebagai faktor risiko kejadian menunjukkan bahwa kualitas air bersih menjadi faktor risiko terhadap kejadian penyakit diare (Santoro, dkk., 2015).

Dari beberapa responden masih ada yang membuang limbah rumah tangganya kesaluran terbuka karena tidak memiliki sarana pembuangan air limbah. Sebagian lain memiliki saluran pembuangan air limbah rumah tangga namun tidak memenuhi syarat. Keadaan tersebut dapat menjadi genangan air kotor yang digunakan mikroorganisme sebagai tempat hidup. Sarana pembuangan tinja juga harus ada dalam mendukung terciptanya derajat kesehatan masyarakat yang optimal. Sarana pembuangan tinja (jamban) mengisolasi tinja agar tidak terjamah oleh vektor yang dapat menyebarkan penyakit diare. Penelitian ini didukung oleh penelitian Susanti, (2018) menyatakan bahwa risiko diare meningkat $(\mathrm{OR}=1,67)$.

Sarana pembuangan air limbah (SPAL) sebagai pendukung terselenggaranya sarana sanitasi yang sehat. SPAL dimaksudkan sebagai upaya pencegahan pencemaran lingkungan oleh air limbah. Hasil ini didukung penelitian Oktariza (2018) menyatakan bahwa SPAL merupakan faktor risiko penyebab diare pada balita (OR 2,59,93) (Oktariza, Suhartono, \& Dharminto, 2018)

Pengelolaan sampah yang buruk berisiko terhadap penyakit berbasis lingkungan. Hasilpenelitianini didukung oleh penelitian Susanti (2018) yang menyatakan bahwa pengelolaan sampah yang buruk berisiko 2,5 kali untuk meyebabkan ISPA dibandingkan dengan pengelolaan sampah yang baik. Hasil pengolahan data menunjukkan masih terdapatrumah yang tidak memiliki sarana pengelolaan sampah. Kondisi ini dapatmengundang lalat selanjutnya menyebarkan penyakit diare dan DBD. Hasil ini sejalan dengan penelitian Hadriyati, dkk (2016) yang menyatakan bahwa terdapat hubungan yang signifikan antara Penyediaan tempat pembuangan sampah dengankejadian DBD diwilayah Kerja Puskesmas Kenali Besar ( $p$-value $=0,002 ; p$ vallue $\leq 0,05$ ) (Hadriyati, Marisdayana, \& Ajizah, 2016).

\section{Hubungan Perilaku Penghuni Rumah dengan Penyakit Berbasis Lingkungan}

Setelah aspek komponen fisik rumah dan sarana sanitasi, perilaku penghuni juga merupakan aspek penilaian terhadap sanitasi pemukiman. tabel 1 menerangkan masih terdapat penghuni yang berperilaku tidak sehat $40,1 \%$, dan 59,9\% penghuni sudah berperilaku sehat. Penilaian perilaku penghuni dilihat dari kebiasaan membuka jendela kamar tidur, membuka jendela ruang keluarga, membersihkan rumah dan halaman, membuang tinja balita ke jamban, membuang sampah pada tempat sampah, kebiasaan merokok, dam penggunaan obat nyamuk.

Tabel 2 menjelaskan pada kelompok responden dengan perilaku penghuni tidak sehat, ada $47,4 \%$ menderita penyakit berbasis lingkungan. Pada kelompok responden dengan perilaku penghuni yang sehat terdapat $34,3 \%$ menderita penyakit berbasis lingkungan. Dari analisa secara statistik diperoleh hasil ada hubungan yang bermakna antara perilaku penghuni dengan kejadian penyakit berbasis lingkungan, dimana nilai signifikansi sebesar $0,014(\mathrm{OR}=1,723, \mathrm{CI}=1,135-2,615)$.

Halaman rumah yang bersih mencerminkan kesehatan penghuninya. Terdapat beberapa keluarga yang hanya kadangkala membersihkan rumah dan halamannya bahkan tidak dibersihkan karena tidak tinggal dirumah tersebut. Rumah yang ditinggalkan penghuninya ditumbuhi semak belukar dan menjadi sarang vektor penyakit seperti semut dan kecoa.

Kebiasaan membuka jendela kamar tidur dan membuka jendela ruang keluarga berkontribusi terhadap ketersediaan udara segar dalam ruangan. Selain itu, kualitas air bersih dan ketersediaan jamban dapat berpengaruh terhadap kejadian diare (Hakim, Irfanuddin, Hermansyah, \& Novrikasari, 2018; Irfan \& Sulansi, 2016; (Samiyati, Suhartono, \& Dharminto, 2019). Membuang tinja balita ke jamban dapat mengisolasi tinja sehingga tidak terjamah oleh vektor.

Kebiasaan penghuni rumah lain yang merugikan keluarga adalah kebiasaan merokok yang dilakukan di dalam rumah dan penggunaan obat nyamuk. Adanya asap hasil pembakaran rokok dan obat nyamuk dapat menyebabkan penyakit ISPA. Hasil penelitian ini sejalan dengan penelitian Ahyanti (2013) yang menyatakan bahwa ada hubungan yang bermakna antara perilaku merokok dengan kejadian penyakit ISPA ( $p$-value $=0,025) \quad$ (Ahyanti\& Duarsa, 2013).

\section{Hubungan Sanitasi Pemukiman dengan Penyakit Berbasis Lingkungan}

Sanitasi pemukiman diukur melalui komponen fisik rumah, sarana sanitasi dan perilaku penghuni yang tersaji pada tabel 1 
menjelaskan $47,1 \%$ responden tinggal pada pemukiman yang tidak sehat, dan $52,9 \%$ responden tinggal pada pemukiman sehat.

Dari hasil analisis statistik pada tabel 2 terlihat, pada kelompok responden dengan sanitasi pemukiman tidak sehat terdapat $51,9 \%$ menderita penyakit berbasis lingkungan. Sedangkan pada kelompok responden dengan sanitasi pemukiman sehat terdapat $28,6 \%$ menderita penyakit berbasis lingkungan. Diperoleh $p$-value $=0,000$ OR $=2,701$, CI $95 \%$ 1,772-4,118. Dari hasil tersebut dapat disimpulkan terdapat hubungan yang bermakna antara sanitasi pemukiman dengan kejadian penyakit berbasis lingkungan di Kota Bandar Lampung.

Hasil ini sejalan dengan penelitian Gapar, dkk (2015) yang menyatakan bahwa kualitas sanitasi rumah memiliki nilai signifikansi $p$ value $=0,000$ (sig $p<0,05)$ (Gapar, Adiputra, \& Pujaastawa, 2015)

Keman (2005) menjelaskan pemukiman kotor yaitu tidak ada penyediaan air bersih, sampah yang menumpuk, kondisi rumah yang sangat menyedihkan, dan banyaknya vector penyakit, terutama lalat, nyamuk dan tikus (Keman, 2005).

Dalam pengadaan perumahan, sangat diperlukan peran serta masyarakat. Pemerintah bertindak sebagai fasilitator yang mendorong dan member bantuan untuk mencapai tujuan. Pembangunan perumahan merupakan tanggung jawab dari masyarakat sendiri sehingga potensi dan peran serta masyarakat perlu dikembangkan dalam pembangunan perumahan. Perlu dilaksanakan pemberdayaan masyarakat dalam pengadaan dan pemeliharaan sanitasi pemukiman. Sebagai contoh adalah pendampingan dalam pengadaan sarana sanitasi jamban keluarga.

\section{DAFTAR PUSTAKA}

Achmadi. (2008). Perubahan Ekologi dan Aspek Perilaku Vektor, Direktorat Jenderal Pemberantasan Penyakit Menular dan Penyehatan Lingkungan. Jakarta: Departemen Kesehatan Republik Indonesia.

Ahyanti, M., \& Duarsa, A. (2013). Hubungan merokok dengan kejadian ispa pada mahasiswa politeknik kesehatan kementerian kesehatan tanjungkarang. Jurnal Kesehatan Masyarakat, 7(2), 47-53.

Ambarwati, M. (2019). Correlation Between
Klinik sanitasi sebagai salah satu wadah yang dapat digunakan oleh sanitarian dan pasien penyakit berbasis lingkungan untuk saling berinteraksi dan berkonsultasi tentang masalah kesehatan. Klinik sanitasi telah ada sejak tahun 2003, akan tetapi di banyak tempat program klinik sanitasi seperti tidak berjalan, tidak ada tanda-tanda kehidupan, dengan berbagai permasalahan dan alasan. Kalaupun ada, kegiatan klinik sanitasi seolah bergerak tanpa makna.

Klinik sanitasi adalah suatu upaya yang dilakukan secara terintegrasi dalam memberikan pelayanan kesehatan promotif, preventif, dan kuratif yang difokuskan pada penduduk berisiko tinggi. Klinik sanitasi merupakan satu wadah dalam masyarakat yang sebagai upaya mengatasi masalah kesehatan lingkungan. Dalam upaya pemberantasan penyakit, masyarakat sangat memerlukan penyuluhan, bantuan, dan bimbingan teknis dari petugas puskesmas baik secara pasif dan aktif di dalam dan di luar gedung. Sangat penting untuk menghidupkan kembali klinik sanitasi, karena melalui klinik sanitasi dapat dilakukan kegiatan konseling. Kegiatan konseling sangat membantu masyarakat dalam mengatasi masalah kesehatannya.

\section{SIMPULAN}

Hasil analisis menyimpulkan terdapat hubungan yang bermakna antara sanitasi pemukiman dengan kejadian penyakit berbasis lingkungan. Penting bagi Puskesmas untuk menghidupkan kembali kegiatan klinik sanitasi sebagai upaya yang terintegrasi untuk memberikan pelayanan promotif, preventif dan kuratif dalam mengatasi maslaah kesehatan lingkungan di masyarakat.

Coverage of Bcg Immunisation and. Jurnal Berkala Epidemiologi, 7(3), 207-216. https://doi.org/10.20473/jbe.v7i32019.

Ariawan, I. (1998). Besar dan Metode Sampel pada Penelitian Kesehatan. Jakarta: FKM UI.

Boyd, D. R., \& Genuis, S. J. (2008). The environmental burden of disease in Canada: Respiratory disease, cardiovascular disease, cancer, and congenital affliction. Environmental Research, Vol. 106, pp. 240249. 
https://doi.org/10.1016/j.envres.2007.08.009

Darnas, Y., \& Yolanda, R. (2019). The Relationship between Sanitation and Diarrhea in Kabupaten Pidie, Aceh (Used Validity Inference). KnE Life Sciences, 4(10), 422. https://doi.org/10.18502/kls.v4i10.3814

Dinas Kesehatan Kota Bandar Lampung. (2017). Profil Kesehatan Provinsi Kota Bandar Lampung tahun 2016. Bandar Lampung.

Dinas Kesehatan Provinsi Lampung. (2016). Profil Kesehatan Provinsi Lampung. In Dinas Kesehatan Provinsi Lampung. Bandar Lampung.

Hadriyati, A., Marisdayana, R., \& Ajizah. (2016). Hubungan Sanitasi Lingkungan dan Tindakan 3M Plus Terhadap Kejadian DBD. Jurnal Endurance, 1(1), 11-16. https://doi.org/10.22216/jen.v1i1.601

Hakim, M. M., Irfanuddin, I., Hermansyah, H., \& Novrikasari. (2018). The Prevalence of Diarrhea Based on Knowledge and Environmental Sanitation in Tanjung Lago Village Wetland Area. E3S Web of Conferences, 68, 1-6. https://doi.org/10.1051/e3sconf/201868040 13

Irfan, \& Sulansi. (2016). Employment , Knowledge and Latrine Ownership as Risk Factors and Prediction Model of Diarrhea Incidence. International Journal of Public Health Science (IJPHS), 5(2), 158-163. http://iaesjournal.com/online/index.php/IJP HS

Gapar, I. G. S., Adiputra, N., \& Pujaastawa, I. B. G. (2015). Hubungan kualitas sanitasi rumah dengan kejadian penyakit infeksi saluran pernapasan akut (ISPA) di wilayah kerja Puskesmas IV Denpasar Selatan Kota Denpasar. ECOTROPHIC: Jurnal Ilmu Lingkungan (Journal of Environmental Science), 9(2), 41-45.

Keman, S. (2005). Kesehatan Perumahan dan Lingkungan Pemukiman. Jurnal
Kesehatan Lingkungan, 2(1), 29-42.

Mukono. (2006). Prinsip Dasar Kesehatan Lingkungan. Surabaya: Airlangga University Press.

Oktariza, M., Suhartono, S., \& Dharminto, D. (2018). Gambaran Kondisi Sanitasi Lingkungan Rumah Dengan Kejadian Diare Pada Balita Di Wilayah Kerja Puskesmas Buayan Kabupaten Kebumen. Jurnal Kesehatan Masyarakat (e-Journal), 6(4), 476-484.

https://ejournal3.undip.ac.id/index.php/jkm /article/view/21456

Qamila, N., \& Krama, A. V. (2018). Difusi dan Pola Spasial Sebaran Penyakit Demam Berdarah Dengue (DBD) Di Kota Bandar Lampung. KESMARS: Jurnal Kesehatan Masyarakat, Manajemen Dan Administrasi Rumah Sakit, 1(1), 87-95. https://doi.org/10.31539/kesmars.v1i1.192

Samani, Z. N., Karimi, M., \& Alesheikh, A. (2020). Environmental and infrastructural effects on respiratory disease exacerbation: a LBSN and ANN-based spatio-temporal modelling. Environmental Monitoring and Assessment, $\quad$ Vol. 192. https://doi.org/10.1007/s10661-019-7987-x

Samiyati, M., Suhartono, \& Dharminto. (2019). Hubungan Sanitasi Lingkungan Rumah Dengan Kejadian Diare Pada Balita Di Wilayah Kerja Puskesmas Karanganyar Kabupaten Pekalongan. Jurnal Kesehatan Masyarakat (e-Journal), 7(1), 388-395.

Santoro, N. E., Rambi, E. V., \& Katiandagho, D. (2015). Analisis Faktor Risiko Penyakit Berbasis Lingkungan di Kota MAnado Tahun 2013. Infokes, 10(1), 55-67.

Susanti, E. (2018). Risk Factors for Diarrhea Cases in Communities Living Along Deli River, North Sumatera. Journal of Epidemiology and Public Health, 04(01), 47-54.

https://doi.org/10.26911/jepublichealth.201 9.04.01.06 